\title{
STUDI INTEGRASI MODA ANGKUTAN UMUM (STUDI KASUS : STASIUN GARUT BARU, KECAMATAN GARUT KOTA, KABUPATEN GARUT)
}

\author{
Bella Syafira ${ }^{1)}$, Suryono Herlambang ${ }^{2)}$, Parino Rahardjo ${ }^{3)}$
}

\footnotetext{
1)Program Studi S1 PWK, Fakultas Teknik, Universitas Tarumanagara, bsyafira156@gmail.com

2)Program Studi S1 PWK, Fakultas Teknik, Universitas Tarumanagara, s.herlambang@gmail.com

3)Program Studi S1 PWK, Fakultas Teknik, Universitas Tarumanagara, parinor19@gmail.com
}

\begin{abstract}
Abstrak
Transportasi diusahakan agar dapat berjalan secara efektif, berkapasitas dan berkualitas untuk melayani berbagai pusat kegiatan di sebuah kawasan, dan transportasi juga dapat digunakan sebagai elemen untuk pengembangan wilayah. Efektif berarti mencapai sasaran yang telah direncanakan, berkapasitas berarti memiliki fasilitas yang baik untuk sarana dan prasarana tersedia secara cukup, dan berkualitas berarti dapat memberikan pelayanan jasa transportasi yang lancar (cepat), selamat (aman), murah dan nyaman. Transportasi secara masal juga dapat memiliki pengaruh yang besar, salah satunya dapat digunakan untuk menjadi penggerak untuk sektor perekonomian dan pariwisata di suatu wilayah dan kawasan. Transportasi terdiri dari 2 komponen yaitu sarana dan prasarana, sarana transportasi adalah komponen yang digunakan untuk mengangkut penumpang yang ada seperti bus, kereta api, mobil dan motor. Sedangkan prasarana transportasi merupakan komponen penunjang dari sarana transportasi seperti contohnya jalan raya, jalan tol, terminal, stasiun dan pelabuhan. Beberapa unsur penting transportasi agar dapat saling mengintegrasikan titik penting yang ada adalah the vehicle (kendaraan atau moda transportasi), the way (jaringan jalan dan trayek atau rute), the terminal (terminal, halte dan stasiun) dan the passanger (penumpang). Dalam sebuah sistem transportasi, jika kondisinya ada yang kurang baik dari keempat unsur di atas maka masing-masing pusat kegiatan yang ada di sebuah kawasan tidak akan terintegrasi dengan baik.
\end{abstract}

Kata kunci: integrasi; pengembangan wilayah; sektor perekonomian dan pariwisata; stakeholder; Transportasi

\begin{abstract}
Transportation is work on to run with effectively, capacity and quality to serve various hub in an area, and transportation can also be used as an element for regional development. Effectively means achieving the planned targets, capacity means having good facilities for adequate facilities and infrastructure, and quality means being able to provide transportation services that are smooth (fast), safe, cheap and comfortable. Mass transportation can also have a great influence, one of which can be used to become a driving force for the economic and tourism sectors in a area and region. Transportation consists of 2 components, it was a facilities and infrastructure, transportation facilities used to transport the passengers such as bus, trains, cars and motorcycles. Meanwhile, transportation infrastructure is a supporting component of transportation facilities such as roads, toll roads, terminals, stations and ports. Some important elements of transportation that used for integrating some hub in an area are the vehicle (vehicles or modes of transportation), the way (road and routes), the terminal (terminals, bus stops and stations) and the passanger. In a transportation system, if there one element is not in a good condition, then each activity center in an area will not be well integrated.
\end{abstract}

Keywords:, economic and tourism sectors; integration; regional development; stakeholder; transportation 


\section{PENDAHULUAN}

\section{Latar Belakang}

Sejak dahulu, Kabupaten Garut sudah memiliki pesona alamnya sendiri terutama pada masa kolonial, dan menjadi salah satu tujuan wisata penting di Jawa Barat. Namun keindahan alam Kabupaten Garut ini terhambat karena aksesnya yang sulit pada masa kolonial. Hal ini lah yang membuat perusahaan kereta api negara saat itu atau Staatsssporwegen memutuskan untuk membangun jaringan kereta api menuju Garut, dan di tahun 1889 jalur Cicalengka - Garut mulai dibuka untuk umum. Dan selanjutnya di tahun 1921 pembangunan jalur ke Cikajang mulai juga dibangun. Namun kemudian ditutup di tahun 1983 karena banyak penumpang yang beralih menggunakan moda transportasi darat lainnya seperti mobil dan bus.

Dalam Rencana Induk Perkeretaapian Nasional (RIPNAS) Tahun 2018, di wilayah Jawa Barat ada 4 jalur kereta yang akan direaktivasi diantaranya Cicalengka - Jatinangor - Tanjungsari, Banjar Cijulang, Cikudapeteuh - Ciwidey dan Cibatu - Garut - Cikajang ${ }^{1}$. Reaktivasi ke-empat jalur kereta api ini bertujuan untuk mengurangi tingkat kemacetan di jalan raya, waktu untuk distribusi logistik bisa lebih pasti, mempengaruhi pertumbuhan ekonomi di wilayah yang dilintasi jalur kereta api dan untuk mempermudah akses pariwisata. Salah satu jalur kereta yang saat ini sudah di aktifkan kembali adalah Cibatu - Garut - Cikajang dengan progress pembangunan jalur hingga Stasiun Garut Baru sudah siap dan sedang dilakukan pembangunan Stasiun Garut Baru sesuai dengan masterplan yang ada.

Menurut Kepala Bidang Pemasaran Disparbud Jabar, para pengguna jasa kereta api di Jawa Barat memiliki tujuan bukan hanya untuk berpergian antar kota saja tetapi juga untuk melakukan aktivitas ekonomi dan wisata. Tujuan lain dari diaktfkan kembali jalur kereta di Jawa Barat adalah untuk mengurangi kemacetan akses jalan raya, mendorong pertumbuhan ekonomi di wilayah yang dilewati oleh jalur dan stasiun kereta api dan memudahkan akses untuk menuju lokasi wisata. Di Garut sendiri memiliki 4 pembagian wilayah wisata, namun hanya 1 wilayah yang sudah dilayani oleh transportasi kereta api. Dan dengan adanya reaktivasi ini maka jika dilihat berdasarkan letaknya maka jalur dan stasiun rencana reaktivasi ini telah melayani 3 dari 4 pembagian Kawasan Strategis Pariwisata Kabupaten yang ada di Kabupaten Garut.

\section{Rumusan Permasalahan}

Rumusan masalah dari objek studi ini, Stasiun Garut Baru di reaktivasi dengan tujuan untuk mendorong pertumbuhan ekonomi dan memudahkan akses pariwisata. Sedangkan eksistingnya, akses dari stasiun menuju titik-titik wisata di sekitarnya masih belum memiliki banyak pilihan transportasi sehingga titik wisata di sekitar stasiun dengan Stasiun Garut Baru masih belum terintegrasi satu sama lain.

\section{Tujuan}

Tujuan dari studi ini adalah untuk mengetahui integrasi Stasiun Garut Baru dengan titik wisata dan pusat oleh-oleh yang terletak di sekitar stasiun. Selanjutnya, dalam studi ini penulis ingin mengetahui seberapa besar potensi yang dimiliki stasiun terhadap kawasan sekitar terutama bagi titik wisata di sekitarnya.

\section{KAJIAN LITERATUR}

\section{Transportasi}

Transportasi berasal dari kata transportare dari bahasa latin yang berarti mengangkat atau membawa, maka transportasi berarti membawa sesuatu dari suatu tempat ke tempat yang lainnya. Transportasi berguna untuk mempermudah aktivitas manusia sehari-hari, dan 
merupakan elemen dasar yang berpengaruh terhadap pola perkembangan perkotaan. Setiap perkembangan transportasi berpengaruh pada sekitarnya karena akan mempengaruhi perubahan tata guna lahan, intensitas bangunan, aktivitas perekonomian dan lain-lain.

\section{Sistem Transportasi}

Menurut Sakti Adji Adisasmita (2014), sistem transpotasi nasional dibuat sebagai pedoman untuk pembangunan transportasi dengan tujuan agar dapat terlaksana dengan efektif dan efisien. Efektif berarti selamat, aksesibilitas tinggi, terpadu, kapasitas mencukupi, teratur, lancar dan cepat, mudah dicapai, tepat waktu, nyaman, tarif terjangkau serta polusi rendah. Dan efisien berarti beban publik rendah dan utilitas tinggi dalam kesatuan jaringan transportasi nasional. Tujuan lain dari sistem transportasi nasional adalah sebagai penunjang pergerakan pembangunan, meningkatkan mobilitas manusia, barang dan jasa, membuat pola distribusi nasional yang mendukung pengembangan wilayah, dan untuk mengembangan kehidupan masyarakat

\section{Transportasi Perkotaan}

Menurut Sakti Adji Adisasmita (2014), transportasi perkotaan diusahakan agar dapat berjalan secara efektif, berkapasitas dan berkualitas untuk melayani berbagai pusat kegiatan di kawasan perkotaan. Maksud dari transportasi efektif berarti mencapai sasaran yang telah direncanakan sebelumnya, berkapasitas berarti fasilitas baik prasarana dan sarana transportasi yang disediakan cukup untuk memenuhi kebutuhan yang ada, dan berkualitas berarti dapat memberikan pelayanan jasa transportasi yang lancar (cepat), selamat (aman), murah dan nyaman ke berbagai pusat kegiatan di perkotaan.

Transportasi perkotaan memiliki beberapa unsur penting seperti the vehicle (kendaraan atau moda transportasi), the way (jaringan jalan dan trayek atau rute), the terminal (terminal, halte dan stasiun) dan the passenger (penumpang). Keempat unsur tersebut diorganisasikan dan dioperasikan untuk menyediakan pelayanan transportasi menjadi efektif dan efisien untuk mendukung pergerakan perjalanan penumpang dari berbagai tempat asal ke berbagai tempat tujuan secara lancar, aman, selamat, murah, dan nyaman

\section{Prasarana Transportasi}

Prasarana transportasi adalah sesuatu yang digunakan untuk menunjang sarana transportasi, contohnya jalan raya, jalan tol, terminal, stasiun, pelabuhan, bandara dan rambu-rambu lalu lintas. Prasarana dapat dibagi menjadi dua, yaitu yang berfungsi menjadi penggerak berupa jalur gerak seperti jalan raya, jalan khusus (jalan tol) dan jembatan. Dan Yang berfungsi sebagai tempat pemberhentian sarana transportasi untuk menaikan dan menurunkan penumpang atau barang berupa stasiun bus, halte, stasiun kereta api, pelabuhan dan bandara.

\section{Kawasan Strategis}

Kawasan Strategis Kabupaten (KSK) adalah wilayah yang dipriotitaskan penataan ruangnya karena dianggap memiliki pengaruh yang sangat penting untuk ruang lingkup kabupaten. Kawasan Strategis Kabupaten memiliki pengaruh terhadap beberapa sektor penting, diantaranya sektor ekonomi, sosial, budaya dan lingkungan. Salah satu contoh KSK adalah Kawasan Strategis Pariwisata Kabupaten (KSPK) merupakan kawasan yang ditetapkan sebagai kawasan wisata karena dianggap memiliki potensi untuk pengembangan wisata dan memiliki pengaruh yang penting terhadap beberapa aspek seperti pertumbuhan sektor ekonomi serta melakukan pemberdayaan sumber daya alam dan sumber daya manusia. Ada juga Kawasan Pengembangan Pariwisata Kabupaten (KPPK) yang merupakan kawasan pariwisata dengan karakteristik objek wisata berupa pariwisata alam, budaya dan buatan. 


\section{Pariwisata}

Menurut Oka A. Yoeti (2010) pariwisata merupakan perjalanan untuk bersenang-senang, jika tidak mencari kesenangan maka perjalanan yag dilakukan tidak dapat dikategorikan sebagai perjalanan wisata. Kepariwisataan sendiri dapat didefinisikan sebagai sebuah kegiatan yang terkait dengan pariwisata sebagai wujud kebutuhan bagi setiap orang dan negara selain itu interaksi antara wisatawan dengan masyarakat lokal, antar wisatawan, pemerintah, pemerintah daerah dan pengusaha. Pariwisata dapat dikatakan menarik jika memenuhi syarat something to see, something to do dan something to buy.

\section{Penataan Ruang}

Ruang yang tersedia saat ini dapat dikatakan terbatas terutama untuk di wilayah perkotaan, sehingga dibutuhkan pengaturan untuk mencegah terjadinya konflik karena banyak pihak yang terlibat dalam pemanfaatan ruang. Penataan sendiri memiliki makna upaya untuk memaksimalkan pemanfaatan ruang sehingga dapat meningkatkan pertumbuhan ekonomi, meningkatkan kesejahteraan penduduk dan mencegah adanya pemanfaatan ruang yang terlalu berlebihan sehingga berdampak buruk pada lingkungan. Penataan ruang merupakan sistem yang terdiri dari perencanaan tata ruang, pemanfaatan ruang dan pengendalian pemanfaatan ruang. Perencanaan tata ruang adalah proses awal untuk menentukan struktur ruang dan pola ruang.

Penataan ruang juga memiliki berbagai peran seperti untuk menghasilkan kondisi kualitas kehidupan yang lebih baik, memerlukan peran dari masyarakat untuk berpartisipasi untuk tujuan efisiensi dan mempersiapkan tantangan di kemudian hari. Selain itu sasaran utama dari penataan ruang utamanya di wilayah perkotaan adalah untuk terkendalinya pembangunan wilayah, adanya arahan untuk mengembangkan sistem pusat permukiman dengan pusat lainnya dan adanya kordinasi untuk pembangunan antar wilayah dan antar sektor.

\section{Pengembangan Wilayah}

Di Indonesia, Konsep Pengembangan wilayah nasional memiliki beberapa tujuan, diantaranya adalah untuk membuat pertumbuhan antar daerah menjadi seimbang, memperkokoh kesatuan ekonomi dan efisiensi pertumbuhan. Proses dari berkembangnya suatu wilayah berlangsung dengan mengikuti sebuah mekanisme tertentu yang seringkali disebut mekanisme pengembangan. dan memiliki satuan tertentu yang seringkali disebut sebagai Satuan Wilayah Pengembangan (SWP). Dan dengan berlangsungnya proses berkembangnya suatu wilayah maka tingkat kemudahan pun juga akan meningkat. Dan dengan adanya peningkatan kemudahan ini maka kesempatan untuk pertumbuhan bagi sektor kegiatan usaha pun lebih tinggi dan tentunya hal ini akan mendorong tingginya tingkat perpindahan penduduk

\section{Stakeholder}

Stakeholder merupakan pihak, pelaku atau sering juga disebut sebagai pihak-pihak yang terlibat dalam suatu permasalahan atau sebuah perencanaan. Menurut Biset (1998), stakeholder merupakan orang yang memiliki kepentingan atau perhatian dalam sebuah permasalahan. Berdasarkan kekuatan, posisi dan pengaruh stakeholder dalam sebuah permasalahan, stakeholder dapat dikelompokan menjadi beberapa kelompok, beberapa kelompok tersebut adalah stakeholder utama (primer) yaitu masyarakat, stakeholder pendukung (sekunder) contohnya lembaga swadaya masyarakat, dan stakeholder kunci yang merupakan lembaga resmi seperti Pemerintah Pusat, Pemerintah Provinsi, DPR atau DPRD ataupun Dinas terkait.

\section{METODE}

Data yang telah dikumpulkan dalam studi ini adalah mengenai data dasar Kabupaten Garut, yaitu batas administrasi, daftar kecamatan, dan jumlah penduduk. Lalu ada juga data mengenai 
rencana dari Kabupaten Garut seperti RTRW dan RIPPDA. Selain itu ada data mikro yang mengenai kawasan di sekitar Stasiun Garut Baru, yaitu titik wisata primer dan akomodasi dalam KSPK Perkotaan Garut, sarana transportasi di sekitar stasiun, zonasi kawasan sekitar, dan proyeksi penumpang Stasiun Garut Baru.

Data-data tersebut didapatkan dengan menggunakan 2 teknik pengumpulan data yaitu data primer dan data sekunder. Data primer didapatkan dengan cara survey lapangan, melakukan wawancara dengan beberapa dinas seperti Dinas Perhubungan dan Dinas Pariwisata dan Kebudayaan Kabupaten Garut. Sedangkan data sekunder didapatkan dengan cara melihat laporan, dokumen atau catatan dari instansi terkait baik dengan meminta secara langsung atau dengan melihat dokumen yang tersedia secara online. Terakhir, data tersebut diolah dengan menggunakan analisis deskriptif dan analisis deskriptif kualitatif.

\section{DISKUSI DAN HASIL}

\section{Analisis Kondisi Pariwisata}

Analisis kondisi pariwisata ini dilakukan untuk melihat kondisi pariwisata di KSPK Perkotaan Garut. Hal ini guna untuk mengetahui perkembangan wisata dan potensi di dalam kawasan dengan memproyeksikan jumlah wisatawan di kemudian hari dan mencoba membuat skenario untuk mendukung potensi dari stasiun terhadap titik wisata disekitar stasiun.
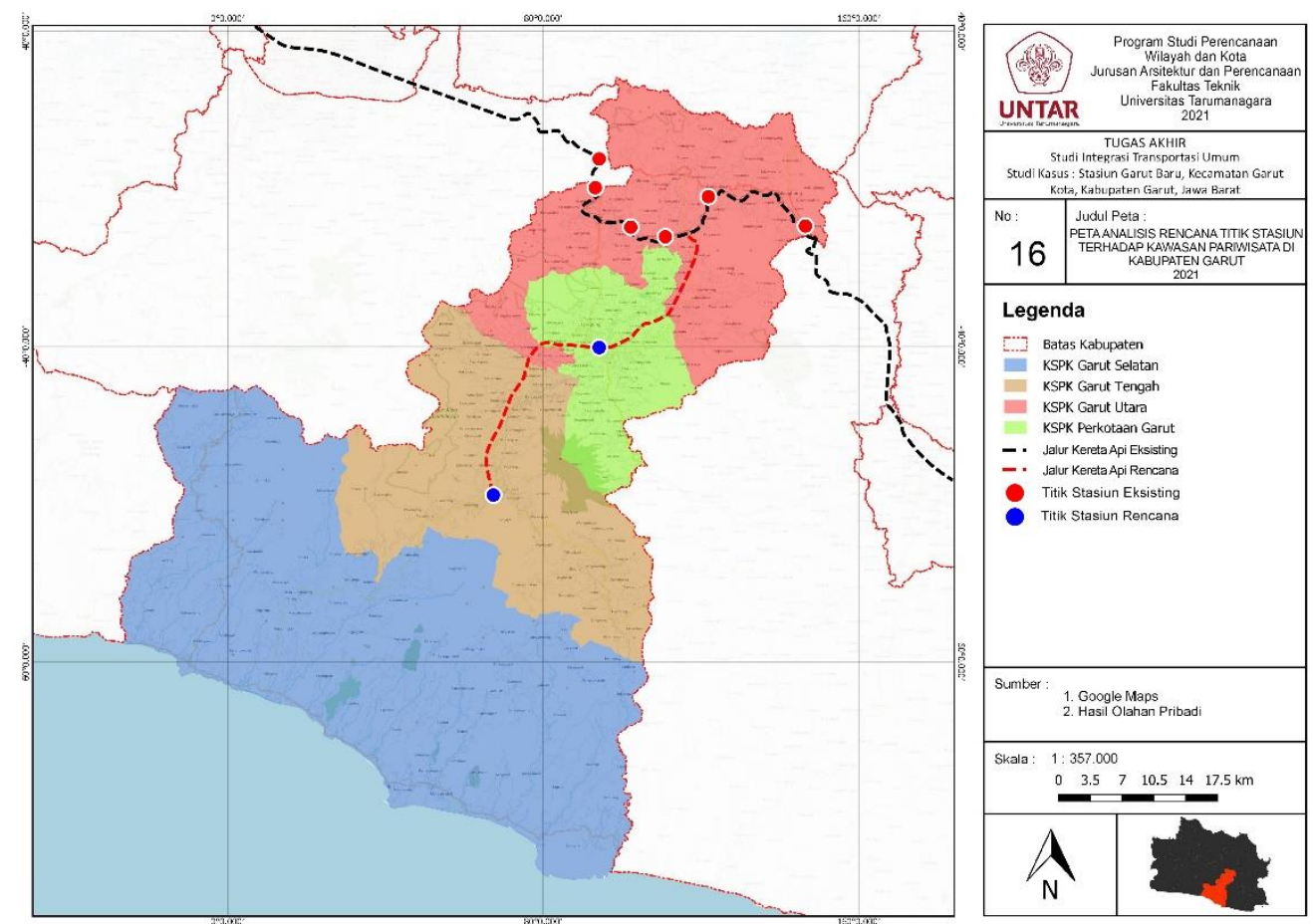

Gambar 1. Overlay Rencana Titik Stasiun terhadap Kawasan Pariwisata di Kabupaten Garut

Sumber : Penulis, 2021

Berdasarkan kondisi eksistingnya, wilayah dari Kabupaten Garut saat ini hanya di bagian utara yang dilayani oleh 4 stasiun operasional penumpang atau hanya bagian KSPK Garut Utara, sedangkan untuk KSPK Perkotaan Garut, KSPK Garut Tengah dan KSPK Garut Selatan masih beum terlayani oleh jalur dan stasiun kereta api. Dari peta di atas dapat dilihat bahwa dalam rencana reaktivasi jalur kereta api Cibatu - Garut - Cikajang terdapat 2 stasiun yang direncanakan akan direaktivasi, yaitu Stasiun Garut Baru dan Stasiun Cikajang. Dimana dalam peta dapat terlihat bahwa dalam rencana Stasiun Cikajang dapat melayani KSPK Garut Tengah 
dan juga dapat membantu kemudahan transportasi untuk KSPK Garut Selatan. Selain Stasiun Cikajag, Stasiun Garut Baru berdasarkan peta di atas letaknya dinilai dapat menunjang Kawasan Strategis Pariwisata Perkotaan Garut. Dalam Kawasan Strategis Pariwisata Perkotaan Garut. Dalam KSPK Perkotaan Garut terdapat 8 objek wisata dan pusat oleh-oleh yang berstatus primer dan dari 8 objek wisata tersebut telah memenuhi syarat something to see, something to do, dan something to buy sehingga dapat dikatakan menarik untuk dikunjungi.

Berdasarkan data yang ada, dapat dilihat bahwa memang jumlah wisatawan di Kabupaten Garut terus bertambah secara signifikan dari tahun 2015 - 2019. Ditahun 2016 dan 2017, jumlah wisatawan yang ada masih belum mencapai target dari Dinas Pariwisata dan Kebudayaan Kabupaten Garut, namun setelah tahun 2018 jumlah realisasi wisatawan yang ada mulai kembali sesuai dengan target yang sudah ditentukan oleh Dinas Pariwisata dan Kebudayaan Kabupaten Garut. Dari data pertumbuhan itu, maka dapat dibuat analisis proyeksi wisatawan di Kabupaten Garut untuk 5 tahun kedepan dengan skenario pesimis, moderat dan optimis.

Tabel 1. Perhitungan Persentase Pertumbuhan Wisatawan dengan Skenario Pesimis, Moderat dan Optimis

\begin{tabular}{cccccccc}
\hline \multirow{2}{*}{ No. } & Tahun & \multicolumn{7}{c}{ Wisatawan } \\
\cline { 3 - 8 } & & \multicolumn{2}{c}{ Pesimis } & \multicolumn{7}{c}{ Moderat } & \multicolumn{2}{c}{ Optimis } \\
\hline $\mathbf{1}$ & 2015 & $2,448,967$ & - & $2,448,967$ & - & - & - \\
\hline $\mathbf{2}$ & 2016 & $2,489,536$ & $1.66 \%$ & $2,489,536$ & $1.66 \%$ & - & - \\
\hline $\mathbf{3}$ & 2017 & $2,517,232$ & $1.11 \%$ & $2,517,232$ & $1.11 \%$ & $2,517,232$ & - \\
\hline $\mathbf{4}$ & 2018 & - & - & $2,756,478$ & $9.50 \%$ & $2,756,478$ & $9.50 \%$ \\
\hline $\mathbf{5}$ & 2019 & - & - & $2,874,966$ & $4.30 \%$ & $2,874,966$ & $4.30 \%$ \\
\hline & Rata-rata & - & $\mathbf{1 . 3 8 \%}$ & - & $\mathbf{4 . 1 4 \%}$ & - & $\mathbf{6 . 9 0 \%}$ \\
\hline
\end{tabular}

Sumber : Penulis, 2021

Tabel 2. Proyeksi Jumlah Wisatawan Kabupaten Garut dengan Skenario Pesimis, Moderat dan Optimis Tahun $2021-2025$

\begin{tabular}{|c|c|c|c|c|c|c|c|}
\hline \multirow{3}{*}{ No. } & \multirow{3}{*}{ Tahun } & \multicolumn{6}{|c|}{ Wisatawan } \\
\hline & & \multicolumn{2}{|c|}{ Pesimis } & \multicolumn{2}{|c|}{ Moderat } & \multicolumn{2}{|c|}{ Optimis } \\
\hline & & Jumlah & $\%$ & Jumlah & $\%$ & Jumlah & $\%$ \\
\hline 1 & 2021 & $2,955,127$ & $1.38 \%$ & $3,118,119$ & $4.14 \%$ & $3,285,487$ & $6.90 \%$ \\
\hline 2 & 2022 & $2,996,042$ & $1.38 \%$ & $3,247,302$ & $4.14 \%$ & $3,512,232$ & $6.90 \%$ \\
\hline 3 & 2023 & $3,037,523$ & $1.38 \%$ & $3,381,838$ & $4.14 \%$ & $3,754,627$ & $6.90 \%$ \\
\hline 4 & 2024 & $3,079,579$ & $1.38 \%$ & $3,521,947$ & $4.14 \%$ & $4,013,749$ & $6.90 \%$ \\
\hline 5 & 2025 & $3,122,217$ & $1.38 \%$ & $3,667,860$ & $4.14 \%$ & $4,290,756$ & $6.90 \%$ \\
\hline
\end{tabular}

Menurut wawancara dengan Dinas Pariwisata dan Kebudayaan Kabupaten Garut, ditargetkan $50 \%$ dari penumpang yang datang ke Kabupaten Garut dengan kereta api merupakan wisatawan yang akan berlibur di Garut. Sehingga dari total sebanyak 143.080 penumpang yang akan berhenti dan turun di Stasiun Garut Baru, 50\% nya ditargetkan menjadi wisatawan yang akan berwisata di Kabupaten Garut nantinya. Maka dapat dihitung, akan ada sekitar 71.540 penumpang yang di targetkan menjadi wisatawan bagi KSPK Perkotaan Garut.

Selain perhitungan di atas, penulis juga membuat perhitungan tambahan jika diadakan penambahan jumlah trip menuju Stasiun Garut Baru di waktu-waktu tertentu seperti di weekend dan saat libur panjang. Penulis mensimulasikan terdapat penambahan 2 trip menuju 
Stasiun Garut Baru di setiap weekend (sabtu dan minggu) dengan estimasi sebanyak 96 hari selama setahun dan 2 kali libur panjang dalam 1 tahun dengan estimasi sebanyak 28 hari (2 minggu untuk 1 kali libur panjang). Penulis juga mengestimasikan load factor untuk simulasi ini adalah sebesar $95 \%$, karena diasumsikan setiap weekend dan libur panjang tiket untuk masingmasing trip dapat terjual hampir seluruhnya dan penumpang yang akan turun atau berhenti di Stasiun Garut Baru diestimasikan tetap sebesar $60 \%$ dari total estimasi penumpang per-tripnya. Dan dari perhitungan tersebut didapatkan total hasil sebanyak 109,558 penumpang yang akan menjadi wisatawan bagi KSPK Perkotaan Garut.

\section{Analisis Konektivitas dan Integrasi}

Konektivitas seringkali disebut sebagai atribut dalam desain perkotaan yang bersifat positif, karena seringkali dirancang untuk memudahkan pergerakan dari perkotaan agar sistem pergerakan yang ada akan terus terhubung. Dan dalam Transit Connectivity Plan (2005), dikatakan bahwa konektivitas yang baik dapat dicapai jika memiliki sistem transit yang baik dan nyaman, waktu perjalanan yang lebih efisien, keberagaman jenis moda transportasi dan juga mudah dalam jenis pembayaran moda transportasi yang ada.

Unsur penting dalam transportasi perkotaan adalah the way atau jaringan jalan dan the vehicle atau pilihan moda transportasi yang dimiliki oleh sebuah kawasan. Oleh karena itu, dilakukan analisis kondisi jalan menuju beberapa titik wisata dan pusat kegiatan yang berada di sekitar Stasiun Garut Baru dan pilihan transportasi yang ada.

Tabel 3. Kondisi Jalan Menuju Titik Wisata dan Pusat Kegiatan

\begin{tabular}{|c|c|c|c|c|c|c|c|c|}
\hline \multirow[b]{2}{*}{ No } & \multirow[b]{2}{*}{ Kawasan } & \multirow[b]{2}{*}{ Nama } & \multirow[b]{2}{*}{ Jarak } & \multicolumn{2}{|c|}{ Transportasi } & \multirow{2}{*}{$\begin{array}{l}\text { Jalan } \\
\text { Kondisi }\end{array}$} & \multicolumn{2}{|c|}{ Waktu Tempuh } \\
\hline & & & & $\begin{array}{c}\text { Jenis } \\
\text { Transportasi }\end{array}$ & $\begin{array}{c}\text { Ketera- } \\
\text { ngan }\end{array}$ & & $\begin{array}{c}\text { Kendaraan } \\
\text { Pribadi }\end{array}$ & $\begin{array}{l}\text { Angkutan } \\
\text { Kota }\end{array}$ \\
\hline \multirow[t]{10}{*}{1} & \multirow{10}{*}{$\begin{array}{l}\text { Kawasan } \\
\text { Cipanas }\end{array}$} & \multirow{5}{*}{$\begin{array}{l}\text { (1) } \\
\text { Pemand } \\
\text { ian } \\
\text { Cipanas }\end{array}$} & \multirow{5}{*}{$\begin{array}{l}7,5 \\
\mathrm{~km}\end{array}$} & (1) Angkutan & \multirow{5}{*}{$\begin{array}{c}\text { Angkot } \\
04\end{array}$} & \multirow[t]{5}{*}{ Baik } & \multirow{5}{*}{$\begin{array}{l}15-20 \\
\text { menit }\end{array}$} & \multirow{5}{*}{$\begin{array}{c}30-35 \\
\text { menit }\end{array}$} \\
\hline & & & & Kota & & & & \\
\hline & & & & $(2)$ & & & & \\
\hline & & & & Kendaraan & & & & \\
\hline & & & & Pribadi & & & & \\
\hline & & (2) TWA & \multirow[t]{5}{*}{$8 \mathrm{~km}$} & (1) & - & \multirow[t]{5}{*}{ Baik } & \multirow{5}{*}{$\begin{array}{l}15-20 \\
\text { menit }\end{array}$} & \multirow[t]{5}{*}{-} \\
\hline & & Gunung & & Kendaraan & & & & \\
\hline & & \multirow[t]{3}{*}{ Guntur } & & Pribadi & & & & \\
\hline & & & & (2) Angkutan & & & & \\
\hline & & & & Sewa & & & & \\
\hline \multirow[t]{5}{*}{2} & \multirow{5}{*}{$\begin{array}{l}\text { Kawasan } \\
\text { Kampung } \\
\text { Situ } \\
\text { Bagendit }\end{array}$} & \multirow{5}{*}{$\begin{array}{l}\text { (3) Situ } \\
\text { Bagendi } \\
t\end{array}$} & \multirow{5}{*}{$\begin{array}{l}9,6 \\
\mathrm{~km}\end{array}$} & (1) Angkutan & \multirow{5}{*}{$\begin{array}{c}\text { Angkot } \\
07\end{array}$} & \multirow{5}{*}{$\begin{array}{c}\text { Perbaika } \\
\mathrm{n}\end{array}$} & \multirow[t]{5}{*}{30 menit } & \multirow{5}{*}{$\begin{array}{l}40-50 \\
\text { menit }\end{array}$} \\
\hline & & & & Kota & & & & \\
\hline & & & & (2) & & & & \\
\hline & & & & Kendaraan & & & & \\
\hline & & & & Pribadi & & & & \\
\hline \multirow[t]{7}{*}{3} & \multirow{7}{*}{$\begin{array}{c}\text { Kawasan } \\
\text { Garut } \\
\text { Kota - } \\
\text { Tarogong } \\
\text { Kaler dan } \\
\text { Kidul - } \\
\text { Karangpa } \\
\text { witan dan }\end{array}$} & (4) & $2 \mathrm{~km}$ & (1) Angkutan & \multirow{5}{*}{$\begin{array}{l}\text { Angkot } \\
01\end{array}$} & \multirow[t]{5}{*}{ Baik } & \multirow{5}{*}{$\begin{array}{l}5-10 \\
\text { menit }\end{array}$} & $25-30$ \\
\hline & & $\begin{array}{l}\text { Pabrik } \\
\text { dan }\end{array}$ & & Kota & & & & menit \\
\hline & & Galeri & & (2) & & & & \\
\hline & & Dodol & & Kendaraan & & & & \\
\hline & & Picnic & & Pribadi & & & & \\
\hline & & (5) & 1,4 & (1) Angkutan & Angkot & Baik & $5-7$ menit & $15-20$ \\
\hline & & Centra & $\mathrm{km}$ & Kota & 01 & & & menit \\
\hline
\end{tabular}




\begin{tabular}{|c|c|c|c|c|c|c|c|c|}
\hline \multirow[b]{2}{*}{ No } & \multirow[b]{2}{*}{ Kawasan } & \multirow[b]{2}{*}{ Nama } & \multirow[b]{2}{*}{ Jarak } & \multicolumn{2}{|c|}{ Transportasi } & \multirow{2}{*}{$\begin{array}{l}\text { Jalan } \\
\text { Kondisi }\end{array}$} & \multicolumn{2}{|c|}{ Waktu Tempuh } \\
\hline & & & & $\begin{array}{c}\text { Jenis } \\
\text { Transportasi }\end{array}$ & $\begin{array}{c}\text { Ketera- } \\
\text { ngan }\end{array}$ & & $\begin{array}{c}\text { Kendaraan } \\
\text { Pribadi }\end{array}$ & $\begin{array}{l}\text { Angkutan } \\
\text { Kota }\end{array}$ \\
\hline & \multirow[t]{5}{*}{$\begin{array}{c}\text { sekitarny } \\
\text { a }\end{array}$} & $\begin{array}{l}\text { Kerajina } \\
\text { n Kulit }\end{array}$ & & $\begin{array}{l}(2) \\
\text { Kendaraan } \\
\text { Pribadi }\end{array}$ & & & & \\
\hline & & $\begin{array}{l}\text { (6) } \\
\text { Kampun } \\
\text { g Tenun } \\
\text { dan } \\
\text { Galeri } \\
\text { Sutra } \\
\text { Alam }\end{array}$ & $\begin{array}{l}3,7 \\
\mathrm{~km}\end{array}$ & $\begin{array}{l}\text { (1) } \\
\text { Kendaraan } \\
\text { Pribadi }\end{array}$ & - & $\begin{array}{c}\text { Kurang } \\
\text { Baik }\end{array}$ & $\begin{array}{c}15-20 \\
\text { menit }\end{array}$ & - \\
\hline & & (7) & $\begin{array}{l}5,2 \\
\mathrm{~km}\end{array}$ & (1) Angkutan & Angkot & Baik & $\begin{array}{l}10-13 \\
\text { menit }\end{array}$ & $40-45$ \\
\hline & & $\begin{array}{l}\text { Pusat } \\
\text { Oleh- } \\
\text { Oleh } \\
\text { Tarogon } \\
\text { g }\end{array}$ & km & $\begin{array}{l}\text { Kota } \\
(2) \\
\text { Kendaraan } \\
\text { Pribadi }\end{array}$ & & & & \\
\hline & & $\begin{array}{l}\text { (8) } \\
\text { Pasar } \\
\text { Kuliner } \\
\text { Ceplak }\end{array}$ & $\begin{array}{c}700 \\
m\end{array}$ & - & $\begin{array}{c}\text { Dapat } \\
\text { dengan } \\
\text { berjalan } \\
\text { kaki }\end{array}$ & Baik & $2-7$ menit & - \\
\hline
\end{tabular}

Sumber : Penulis, 2021

Dari tabel di atas kondisi jalan yang menghubungkan stasiun dengan objek wisata memang sudah baik, namun ada beberapa jalan yang masih. Selain the way, unsur transportasi lainnya yang dianalisa adalah the vehicle atau pilihan transportasi yang tersedia, semakin banyak pilihan transportasi yang ada tentu akan semakin memudahkan pergerakan jaringan transportasi yang ada serta memberikan kenyamanan bagi masyarakat karena dapat memilih jenis moda yang akan digunakan sesuai dengan kebutuhan.
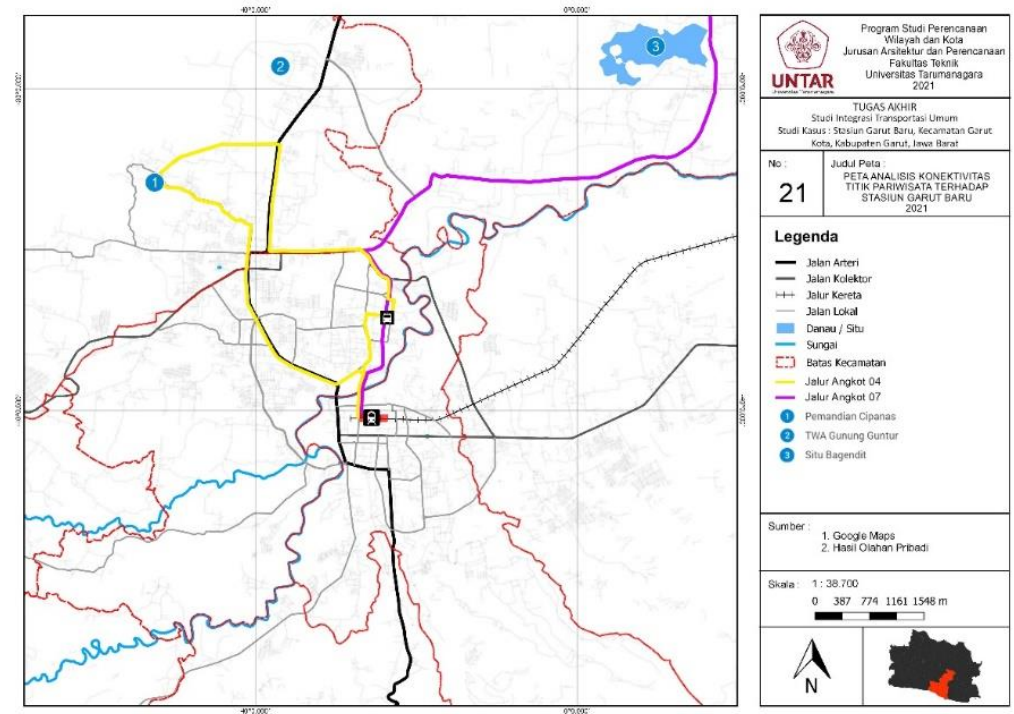

Gambar 2. Konektivitas Titik Pariwisata Terhadap Stasiun Garut Baru Sumber : Penulis, 2021 


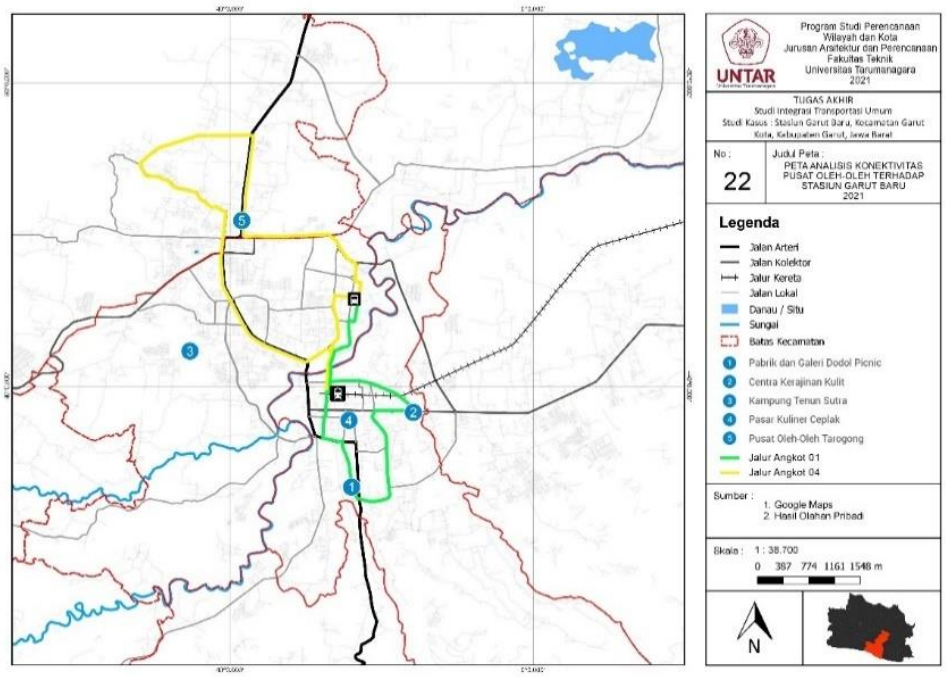

Gambar 3. Konektivitas Titik Kuliner dan Pusat Oleh-Oleh Terhadap Stasiun Garut Baru Sumber: Penulis, 2021

Dari gambar di atas dapat dilihat bahwa hanya 2 titik wisata, 1 pusat kuliner dan 3 kerajinan dan oleh-oleh yang dihubungkan dengan transportasi umum dan itupun hanya dengan satu jenis moda transportasi umum yang berupa angkutan kota (angkot). Yang mana diketahui bahwa belum tentu para wisatawan ingin menggunakan angkot untuk mengakses beberapa titik wisata dan pusat kegiatan di sekitar kawasan Stasiun Garut Baru. Oleh karena itu dapat dikatakan bahwa Stasiun Garut Baru saat ini belum terkoneksi dengan baik oleh titik-titik wisata dan pusat kegiatan yang ada karena hanya dapat diakses oleh kendaraan pribadi dan 1 jenis moda transportasi saja.

Setelah melihat konektivitas antara Stasiun Garut Baru dengan Titik Pariwisata dan Pusat Kegiatan, maka dalam analisis ini akan dilihat konektivitas antara Stasiun Garut Baru dengan Titik Akomodasi yang ada guna untuk menunjang keberadaan titik pariwisata dan pusat kegiatan yang ada.

Tabel 4. Konektivitas Stasiun Garut Baru dengan Fasilitas Akomodasi

\begin{tabular}{|c|c|c|c|c|c|c|c|}
\hline \multirow[b]{2}{*}{ No } & \multirow[b]{2}{*}{ Nama } & \multicolumn{4}{|c|}{ Transportasi } & \multicolumn{2}{|c|}{ Waktu Tempuh } \\
\hline & & Jarak & $\begin{array}{c}\text { Jenis } \\
\text { Transportasi }\end{array}$ & Keterangan & $\begin{array}{l}\text { Kondisi } \\
\text { Jalan }\end{array}$ & $\begin{array}{c}\text { Kendaraan } \\
\text { Pribadi }\end{array}$ & $\begin{array}{c}\text { Angkutan } \\
\text { Umum }\end{array}$ \\
\hline 1 & Fave Hotel & $3 \mathrm{~km}$ & $\begin{array}{l}\text { (1) Angkutan } \\
\text { Kota } \\
\text { (2) Kendaraan } \\
\text { Pribadi }\end{array}$ & Angkot 04 & Baik & 7 menit & 15 menit \\
\hline 2 & $\begin{array}{l}\text { Hotel } \\
\text { Bintang } \\
\text { Redente }\end{array}$ & $\begin{array}{l}4,5 \\
\mathrm{~km}\end{array}$ & $\begin{array}{l}\text { (1) Angkutan } \\
\text { Kota } \\
\text { (2) Kendaraan } \\
\text { Pribadi }\end{array}$ & Angkot 04 & Baik & 8 menit & 18 menit \\
\hline 3 & $\begin{array}{c}\text { Tirtagangga } \\
\text { Hotel }\end{array}$ & $\begin{array}{l}6,9 \\
\mathrm{~km}\end{array}$ & $\begin{array}{l}\text { (1) Angkutan } \\
\text { Kota } \\
\text { (2) Kendaraan } \\
\text { Pribadi }\end{array}$ & Angkot 04 & Baik & 14 menit & 28 menit \\
\hline 4 & $\begin{array}{l}\text { Danau } \\
\text { Dariza }\end{array}$ & $\begin{array}{l}6,4 \\
\mathrm{~km}\end{array}$ & $\begin{array}{l}\text { (1) Angkutan } \\
\text { Kota }\end{array}$ & Angkot 04 & Baik & 13 menit & 30 menit \\
\hline
\end{tabular}




\section{Transportasi}

No Nama Jarak $\begin{gathered}\text { Jenis } \\ \text { Transportasi }\end{gathered}$ Keterangan $\begin{gathered}\text { Kondisi } \\ \text { Jalan }\end{gathered} \begin{gathered}\text { Kendaraan } \\ \text { Pribadi }\end{gathered} \begin{gathered}\text { Angkutan } \\ \text { Umum }\end{gathered}$

\begin{tabular}{|c|c|c|c|c|c|c|c|}
\hline & $\begin{array}{c}\text { Resort } \\
\text { Hotel }\end{array}$ & & $\begin{array}{l}\text { (2) Kendaraan } \\
\text { Pribadi }\end{array}$ & & & & \\
\hline 5 & $\begin{array}{l}\text { Sabda } \\
\text { Alam } \\
\text { Resort } \\
\text { Hotel }\end{array}$ & $\begin{array}{l}6,6 \\
\mathrm{~km}\end{array}$ & $\begin{array}{l}\text { (1) Angkutan } \\
\text { Kota } \\
\text { (2) Kendaraan } \\
\text { Pribadi }\end{array}$ & Angkot 04 & Baik & 13 menit & 30 menit \\
\hline 6 & $\begin{array}{l}\text { Kampung } \\
\text { Sumber } \\
\text { Alam Garut }\end{array}$ & $\begin{array}{l}6,8 \\
\mathrm{~km}\end{array}$ & $\begin{array}{l}\text { (1) Angkutan } \\
\text { Kota } \\
\text { (2) Kendaraan } \\
\text { Pribadi }\end{array}$ & Angkot 04 & Baik & 13 menit & 32 menit \\
\hline 7 & $\begin{array}{c}\text { Hotel } \\
\text { Santika } \\
\text { Garut }\end{array}$ & $\begin{array}{l}6,7 \\
\mathrm{~km}\end{array}$ & $\begin{array}{l}\text { (1) Angkutan } \\
\text { Kota } \\
\text { (2) Kendaraan } \\
\text { Pribadi }\end{array}$ & Angkot 04 & Baik & 12 menit & 38 menit \\
\hline 8 & $\begin{array}{c}\text { Hotel } \\
\text { Harmoni } \\
\text { Garut }\end{array}$ & $\begin{array}{l}7,4 \\
\mathrm{~km}\end{array}$ & $\begin{array}{l}\text { (1) Angkutan } \\
\text { Kota } \\
\text { (2) Kendaraan } \\
\text { Pribadi }\end{array}$ & Angkot 04 & Baik & 14 menit & 35 menit \\
\hline 9 & $\begin{array}{c}\text { Tirta } \\
\text { Kencana } \\
\text { Resort } \\
\text { Hotel }\end{array}$ & $\begin{array}{l}6,6 \\
\mathrm{~km}\end{array}$ & $\begin{array}{l}\text { (1) Angkutan } \\
\text { Kota } \\
\text { (2) Kendaraan } \\
\text { Pribadi }\end{array}$ & Angkot 04 & Baik & 12 menit & 35 menit \\
\hline 10 & $\begin{array}{c}\text { Chandra } \\
\text { Kirana } \\
\text { Hotel }\end{array}$ & $\begin{array}{l}6,6 \\
\mathrm{~km}\end{array}$ & $\begin{array}{l}\text { (1) Angkutan } \\
\text { Kota } \\
\text { (2) Kendaraan } \\
\text { Pribadi }\end{array}$ & Angkot 04 & Baik & 13 menit & 38 menit \\
\hline
\end{tabular}

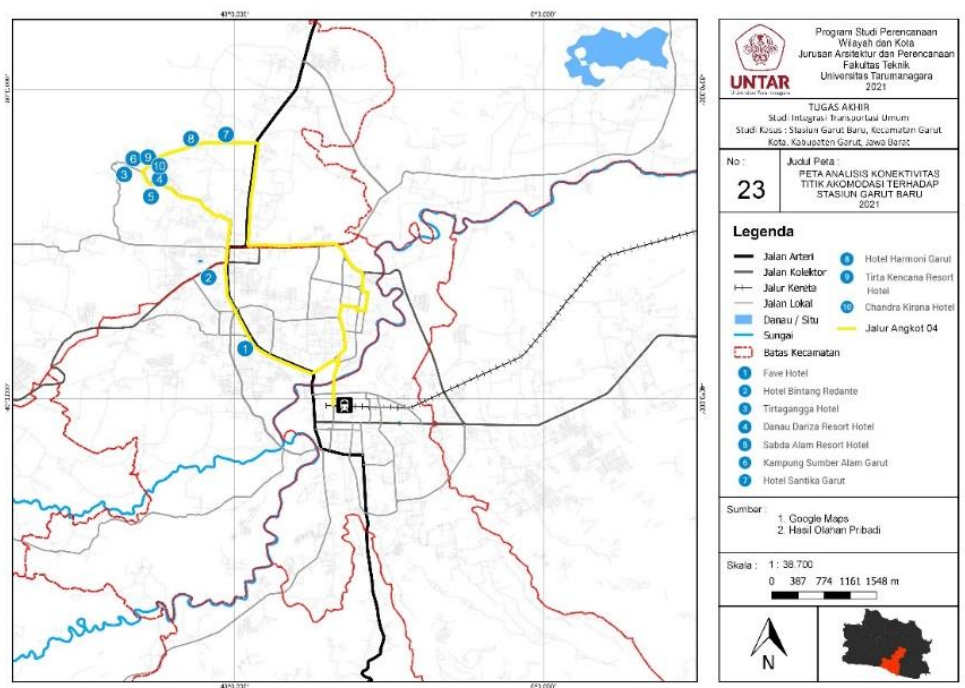

Gambar 4. Konektivitas Jalur Transportasi Mikro Stasiun Garut Baru dengan Fasilitas Akomodasi Sumber : Penulis, 2021 
Dari gambar di atas dapat dilihat bahwa dari 10 fasilitas akomodasi, 8 diantaranya memusat dan berada di Kawasan Pemandian Air Panas Cipanas. Dan kesepuluh fasilitas yang ada hanya terkoneksi oleh satu jenis moda transportasi saja dan hanya satu trayek angkutan umum, yaitu Angkutan Kota 04 atau Angkot Coklat dengan jurusan Terminal Guntur - Cipanas. Dan untuk kondisi jalan dapat diklasifikasikan baik karena memang masih berada di kawasan perkotaan namun jalan berlubang tak jarang juga akan ditemui sepanjang jalan dari dan menuju fasilitas akomodasi yang ada serta seringkali juga macet sehingga menambah lama waktu tempuh yang ada.

Integrasi memiliki arti pembauran untuk menjadi suatu kesatuan yang utuh, berintegrasi berarti bergabung untuk menjadi suatu kesatuan yang utuh dan mengintegrasikan berarti menggabungkan atau menyatukan sesuatu agar menjadi suatu kesatuan yang utuh. Dalam analisis ini akan melihat apakah titik wisata yang ada di sekitar stasiun sudah terintegrasi satu sama lain termasuk dengan Stasiun Garut Baru.
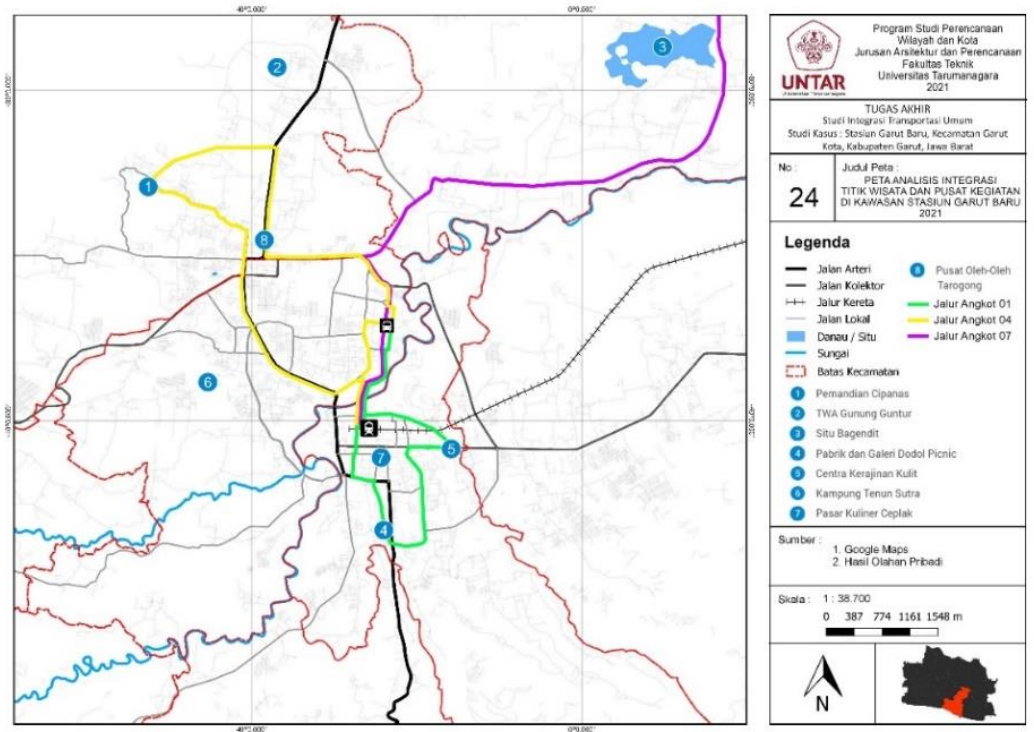

Gambar 5. Integrasi Titik Wisata, Pusat Kuliner dan Oleh-Oleh dengan Stasiun Garut Baru Sumber : Penulis, 2021

Dari peta di atas dapat dilihat bahwa masing-masing titik wisata sudah terintegrasi namun hanya dengan angkutan kota (angkot). Ada 3 jenis angkutan kota yang melayani ke- 6 titik wisata dan pusat oleh-oleh yang ada yaitu angkot 01 , angkot 04 dan angkot 07 . Hal ini masih kurang, karena wisatawan yang datang tidak mungkin menggunakan angkutan kota untuk berpidah dari satu titik wisata ke titik wisata lain atau pusat oleh-oleh. Diperlukan jenis kendaraan lain untuk mengintegrasikan masing-masing titik wisata dan pusat oleh-oleh agar memudahkan perpindahan dari wisatawan yang ingin berkunjung.

\section{Analisis Tapak}

Dalam analisis lokasi dan tapak ini memiliki tujuan untuk mengetahui karakteristik Kawasan Stasiun Garut Baru sehingga dapat mengetahui potensi dan masalah dari Kawasan Stasiun Garut Baru berdasarkan kondisi eksisting yang ada di lapangan. Analisis tapak dilakukan dengan tujuan untuk mengetahui potensi dan masalah dari Kawasan Stasiun Garut Baru berdasarkan kondisi eksisting secara lebih mikro.

Kawasan Sekitar Stasiun Garut Baru didominasi oleh Fungsi Komersil dan perumahan khas perkotaan. Namun karena telah menjadi kawasan perkotaan dan belum ada rencana penataan 
secara detail yang dapat mengatur pola ruang maka timbulah kesan semrawut dan tidak tertata. Selain itu di sekitar kawasan stasiun juga belum banyak memiliki halte ataupun bus stop, hal ini yang menyebabkan para supir angkutan umum seringkali berhenti di sembarang tempat untuk menunggu para penumpang naik ke kendaraannya dan menimbulkan kemacetan.

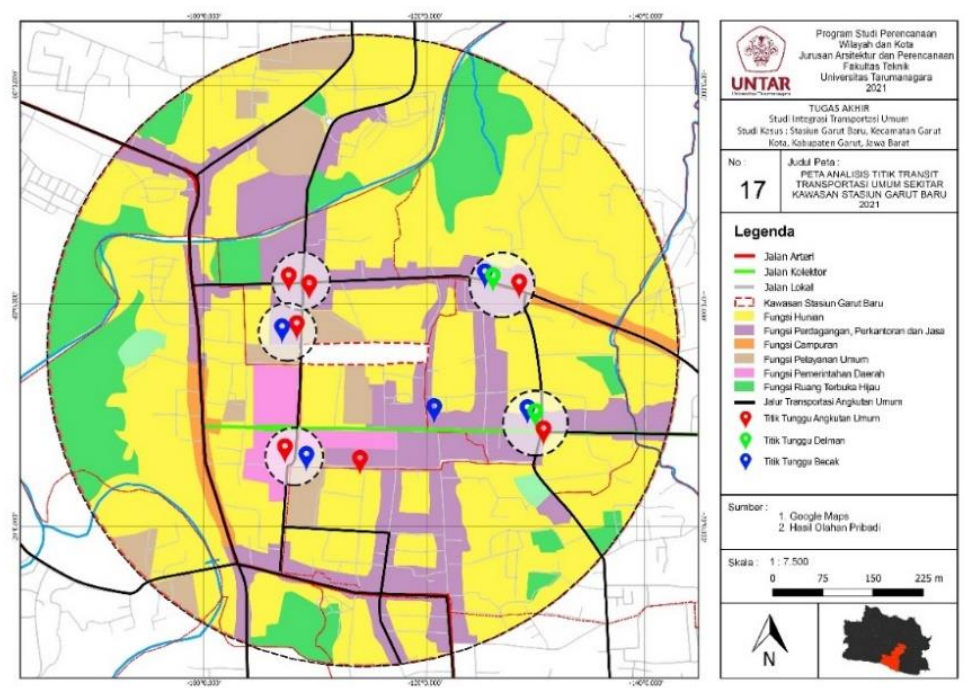

Gambar 6. Analisis Titik Transit Sumber: Penulis, 2021

Kawasan di sekitar stasiun memiliki banyak titik parkir on street, pedagang kaki lima dan juga kendaraan umum yang berhenti di sembarang tempat. Keberadaan titik transit yang tidak direncanakan dengan baik, titik parkir on street dan pedagang kaki lima ini tentu akan berpengaruh pada sirkulasi jalan di sekitar kawasan stasiun sehingga seringkali menimbulkan kemacetan terutama di jam sibuk. Dari peta di atas dapat dilihat bahwa titik transit kebanyakan berada di dekat persimpangan sehingga cukup membuat arus lalu lintas sedikit tersendat karena adanya angkutan umum yang berhenti sehingga menutupi setengah atau bahkan hampir seluruh ruas jalan yang ada. Selain itu keberadaan parkir on street dan pedagang kaki lima juga dapat dilihat berdampingan dengan titik kemacetan sehingga dapat disimpulkan bahwa keberadaan titik transit, parkir on street dan pedagang kaki lima menghambat pergerakan lalu lintas sehingga menimbulkan kemacetan di beberapa titik jalan.
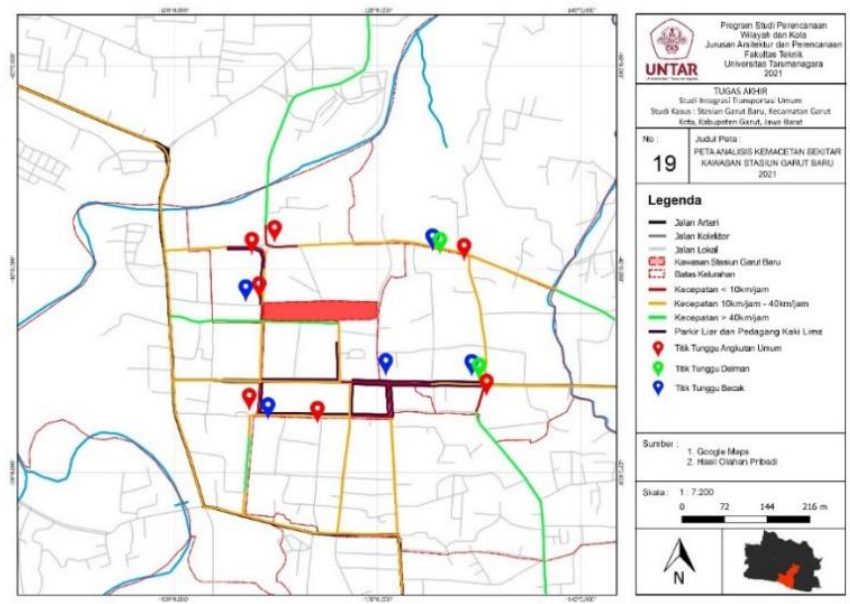

Gambar 7. Peta Analisis Kemacetan Terhadap Titik Transit, Parkir On Street dan Pedagang Kaki Lima Sumber: Penulis, 2021 


\section{Analisis Best Practice}

Dalam analisis ini, penulis akan membandingkan konsep bus wisata di 2 kota berbeda yaitu Jakarta Explorer di Jakarta dan Bandung Tour on Bus atau Bandros di Bandung. Konsep bus wisata Jakarta Explorer sudah lama di operasikan, Program bus wisata tingkat ini digunakan untuk menunjang sektor pariwisata di DKI Jakarta dan merupakan transportasi wisata yang gratis oleh seluruh masyarakat untuk mengelilingi kota Jakarta. Bus tingkat ini beroperasi dengan beberapa jenis rute untuk menelusuri titik penting di kota Jakarta sesuai dengan kategorinya. Selain itu bus ini juga dilengkapi dengan audio untuk memandu menjelaskan titik lokasi yang dilewati.

Selain Kota Jakarta, Kota Bandung juga menyediakan fasilitas bus wisata yang diperuntukan bagi wisatawan yang ingin berkeliling kota yang diberi nama Bandung Tour on Bus atau biasa disingkat menjadi Bandros. Saat ini puluhan unit bandros tersedia dan beroperasi mulai pukul 09.00 hingga 16.00 dan memiliki 5 rute perjalanan yang dibedakan sesuai dengan warna dari masing-masing unit bandros yang beroperasi.

Konsep yang diterapkan oleh Jakarta Explorer mungkin dapat di terapkan di objek studi, karena mengingat Kabupaten Garut memiliki beragam jenis pilihan wisata baik yang sudah berkembang ataupun yang baru di rencanakan oleh Dinas Pariwisata dan Kebudayaan. Para wisatawan dapat mengeksplor berbagai jenis titik wisata sesuai dengan temanya. Sedangkan untuk tipe atau jenis kendaraan yang memungkinkan untuk digunakan dalam penerapan konsep bus wisata ini, penulis menilai jenis bus yang digunakan oleh Bandung City Tour on Bus (Bandros) lebih cocok. Hal ini dikarenakan tipe jalan yang ada di Garut lebih mirip dengan Kota Bandung karena berdasarkan ROW pun jalan di Kota Jakarta jauh lebih lebar dibandingkan dengan jalan yang ada di Garut

\section{KESIMPULAN DAN SARAN}

\section{Kesimpulan}

Dari analisis yang telah dilakukan dalam studi ini, didapatkan beberapa poin kesimpula sebagai berikut ini :

a. Berdasarkan rencana dari reaktivasi jalur kereta Cibatu - Garut - Cikajang, Stasiun Garut Baru secara letak dinilai dapat melayani titik wisata di KSPK Perkotaan Garut. Dan berdasarkan perhitungan yang dilakukan, Stasiun Garut Baru dapat mendatangkan 109,558 wisatawan untuk KSPK Perkotaan Garut terutama ke 8 objek wisata primer di sekitar kawasan stasiun. Ke-8 objek wisata primer di KSPK Perkotan Garut juga dapat dikatakan telah memenuhi syarat wisata yang menarik untuk dikunjungi karena telah memenuhi komponen something to see, something to do dan something to buy.

b. Walau telah memenuhi syarat wisata yang menarik untuk dikunjungi, integrasi ke-8 objek wisata dan Stasiun Garut Baru belum cukup baik karena ketersediaan jenis transportasi yang tersedia sangat terbatas yaitu hanya dengan Angkutan Kota (angkot) atau kendaraan sewa. Berdasarkan kondisi ini penulis melihat kota lain untuk mendukung objek wisatanya. Dan penerapan bus wisata dinilai cocok untuk mendukung integrasi Stasiun Garut Baru dengan ke-8 objek wisata primer di KSPK Perkotaan Garut.

c. Kesimpulan terakhir adalah kawasan di sekitar stasiun sudah sesuai dengan rencana dalam RTRW, hal ini dapat dilihat dengan penggunaan lahan saat ini didominasi oleh fungsi komersial dan perumahan khas perkotaan yang padat. Dan eksistingnya pula belum ada rencana detail yang mengatur kawasan sekitar stasiun sehingga menimbulkan kesan semrawut dan tidak tertata, hal ini dapat dilihat dengan kondisi bangunan yang cukup padat, tidak terpenuhinya kebutuhan parkir sehingga menimbulkan parkir on street, dan banyaknya pedagang kaki lima, serta banyaknya titik berhenti liar angkutan umum karena kurangnya prasarana transportasi seperti halte dan bus stop. 


\section{Saran}

Dari analisis dan kesimpulan yang ada, penulis memberikan saran kepada Pemerintah Kabupaten Garut dan PT KAI. Berikut adalah saran dan usulan untuk Stasiun Garut Baru dan kawasan sekitarnya :

a. Saran yang pertama adalah untuk melakukan penambahan jumlah trip di stasiun untuk waktu-waktu tertentu seperti akhir pekan (sabtu dan minggu) serta untuk libur panjang seperti libur lebaran dan tahun baru. Karena berdasarkan perhitungan hasil simulasi jumlah wisatawan dapat bertambah sebesar 38,018 wisatawan, sehingga dalam setahun Stasiun Garut Baru dapat menghasilkan 109,558 wisatawan untuk KSPK Perkotaan Garut jika penambahan trip dilakukan.

b. Saran yang kedua adalah untuk menambahkan bus wisata agar titik wisata di sekitar stasiun dapat terintegrasi satu sama lain dengan Stasiun Garut Baru. Dan konsep dari Jakarta Explorer dinilai baik untuk diterapkan karena wisatawan dapat mengeksplor segala jenis wisata yang ada di sekitar stasiun dan untuk jenis bus yang digunakan dapat menggunakan bus wisata seperti Bandros karena karakter jalan dari kawasan sekitar stasiun sejenis dengan jalan di Kota Bandung. Berikut adalah usulan rute bus yang diusulkan oleh penulis :
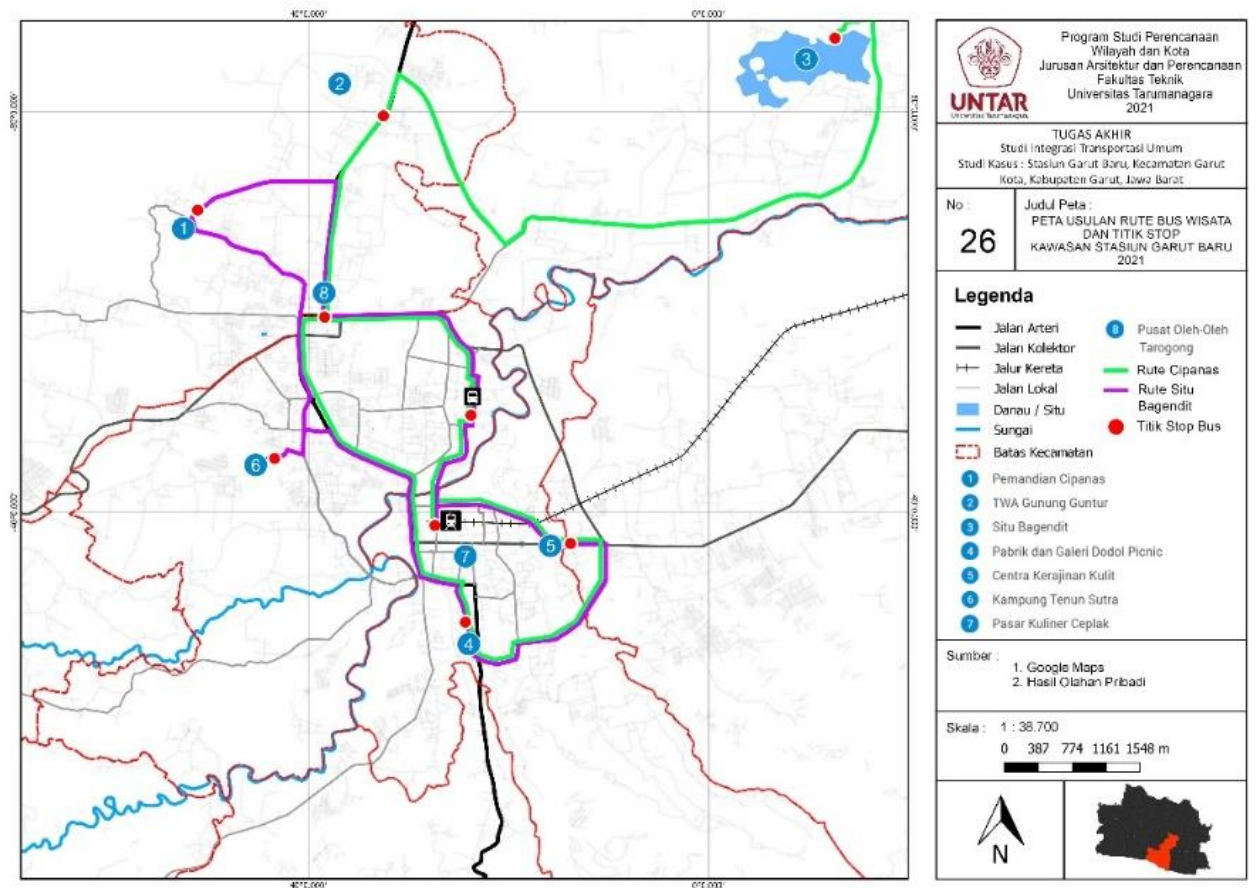

Gambar 8. Usulan Rute Bus Wisata dan Titik Stop Sumber : Penulis, 2021

c. Saran yang terakhir adalah perlu dibuatnya rencana detail untuk mengatur kawasan di sekitar stasiun seperti RDTR untuk Kecamatan Garut Kota. Dan saran untuk permasalahan kemacetan, perlu dilakukan penataan titik transit dan penambahan beberapa prasarana transportasi seperti halte dan kursi tunggu bagi para penumpang kendaraan umum. 

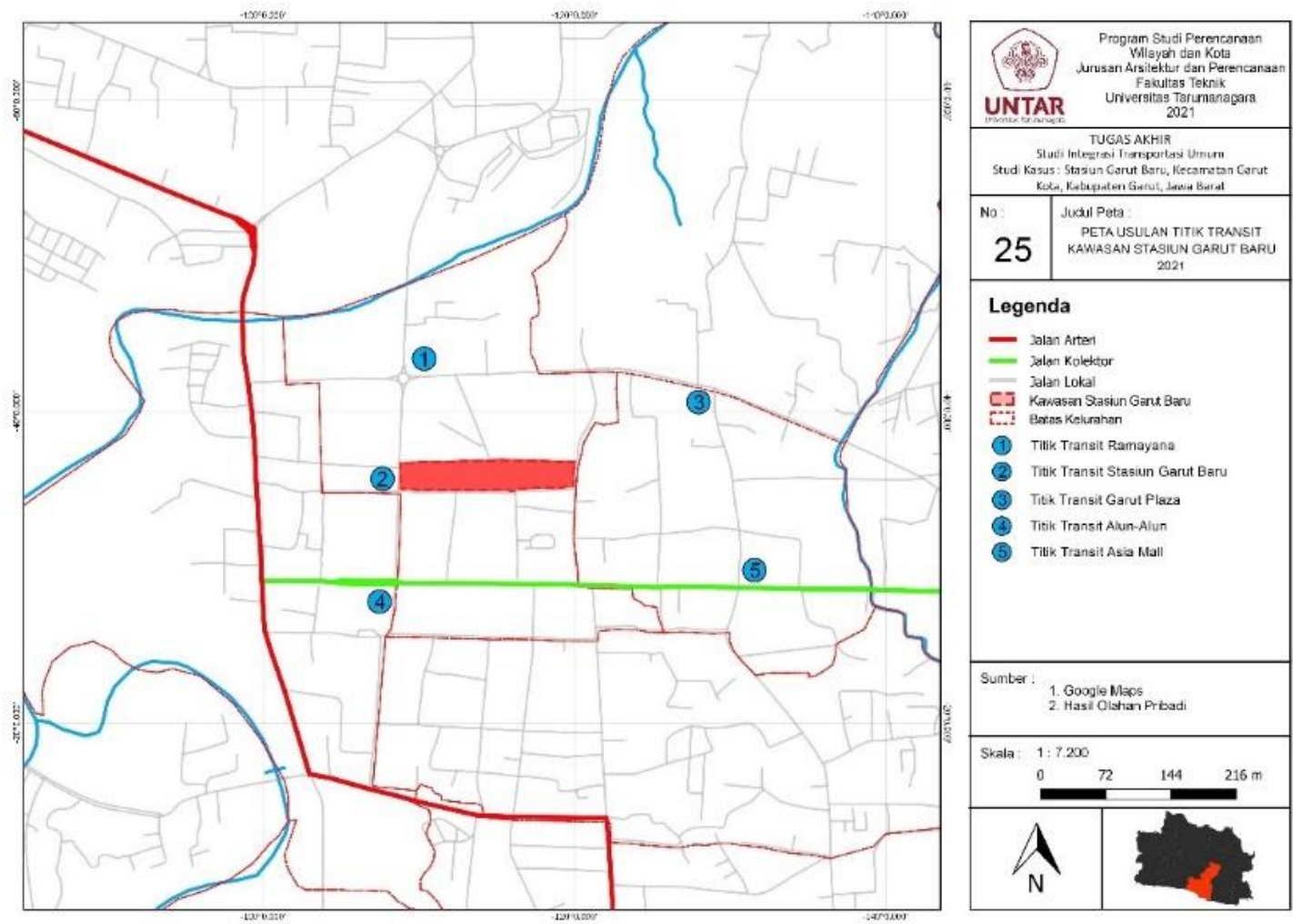

Gambar 9. Usulan Titik Transit di Sekitar Kawasan Stasiun Garut Baru Sumber : Penulis, 2021

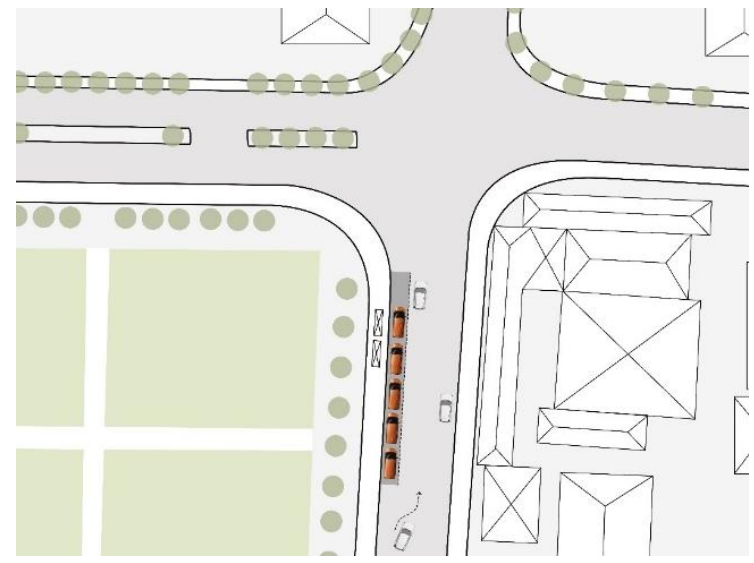

Gambar 10. Ilustrasi Rencana Pembuatan Jalur Khusus Angkutan Umum di Titik Transit Alun-Alun

Sumber : Penulis, 2021

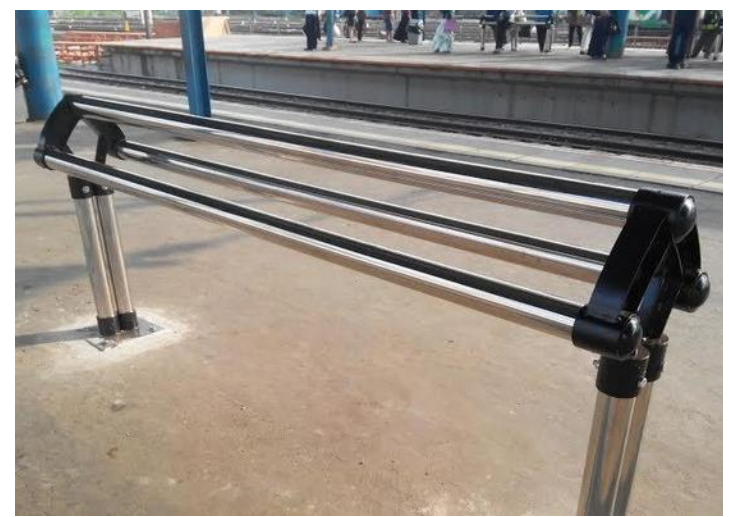

Gambar 11. Contoh Kursi Tunggu untuk Diletakan di Sepanjang Trotoar Sumber : Penulis, 2021

Dari peta di atas usulan titik yang ada tidak jauh berbeda dengan saat ini, hanya saja di beberapa titik transit dijadikan di satu titik sehingga dalam satu area hanya ada 1 titik transit. Dari gambar di atas, dibuat ilustrasi penambahan jalur khusus angkutan umum sehingga angkutan umum yang ingin berhenti untuk memberhentikan atau menurunkan penumpang tidak mengganggu arus lalu lintas bagi kendaraan lainnya. Selain itu dalam ilustrasi di atas penulis mengusulkan penambahan halte dan kursi tunggu bagi para penumpang. Kursi tunggu yang diusulkan juga merupakan kursi tunggu yang berupa sandaran sehingga dapat berfungsi menghalangi keberadaan Pedagang Kaki Lima (PKL) dan menghindari untuk ditiduri tunawisma di malam hari. 


\section{REFERENSI}

Adisasmita, SA. (2014). Perencanaan Sistem Transportasi Publik. Yogyakarta : Graha Ilmu. Hadjisarosa, P. (1981). Konsepsi Dasar Pengembangan Wilayah di Indonesia. Jakarta : DPU.

Menteri Agraria dan Tata Ruang Republik Indonesia. (2016). Peraturan Mentri ATR RI No. 37 Tahun 2016. Jakarta : JDIH BPK RI.

Menteri Perhubungan Republik Indonesia. (2017). Peraturan Menteri Perhubungan RI No. 26 Tahun 2017. Jakarta : JDIH BPK RI.

Yoeti, O.A. (1996). Pengantar Ilmu Pariwisata. Bandung : Angkasa Bandung. 